\title{
Protection of farmers' rights and conservation of agro biodiversity in Nepal
}

\author{
D Gauchan*
}

\begin{abstract}
Farmers' right is considered important to farmers for conservation of agro biodiversity and fostering innovations in agriculture. This paper aims to present findings of the stakeholder survey on the perceptions of farmers' rights and conservation of agro biodiversity in Nepal. The study was carried out in 2006-2007 employing combination of personal interviews, focussed group discussions and consultation meetings to collect perceptions of diverse group of stakeholders $(\mathrm{n}=124)$ on issues related to farmers' rights and conservation of agrobiodiversity. Stakeholders interviewed were farmers, representatives of CBOs, I/NGOs, private sectors, and public sector R \& D organisations including government planners. Findings revealed that agrobiodiversity conservation is important to ensuring food security and improving the livelihood of people. Stakeholders have high priority to protect rights of farmers and local communities to conserve rich biodiversity of agriculture. Farmers' right to seeds, traditional knowledge, benefit sharing and participating in decision makings are their important rights perceived by the stakeholders. A large proportion of stakeholders opined that farmers should be given legal ownership rights to genetic resources and to be involved in sharing benefits arising out of the commercialization of genetic resources. Both governments and farmers should be the main stakeholders for claiming ownerships, facilitating access to genetic resources and sharing benefits arising out from the commercialization of the agrobioresources. Options for establishing institutional mechanisms for ensuring farmers' rights and conservation of agrobiodiversity are suggested both at the local and national level as well.
\end{abstract}

Key words: Agrobiodiversity policy, farmers' rights, genetic erosion, institutional mechanisms.

\section{Agrobiodiversity conservation : context and issues}

Small-scale farmers in Nepal since time immemorial have nurtured and maintained diverse agrobiodiversity resources for their immediate food needs and survival. Several types of crop varieties and animal breeds are domesticated, selected, maintained and conserved over generation by farmers in different ecological regions, farming systems and social contexts. Over generations, farmers have developed traditional knowledge, skills and practices to

${ }^{*}$ Socioeconomics \& Agricultural Research Policy Division, NARC, Khumaltar. devendragauchan@yahoo.co.uk 
grow and use local varieties and their wild relatives for various household social, economic and cultural needs by retaining own seed, recycling for the next planting seasons and exchanging with their neighbors. It is estimated that more than $90 \%$ of the seed required in Nepal are met through this type of informal seed system (Baniya et al, 2003; Gauchan et al., 2003; ADB/MoF, 2010). Farmers' traditional practices of saving and exchanging seeds in the communities are essential for preserving the dynamics of the farming systems, conserving agrobiodiversity and ensuring local food security and livelihood of resource poor farmers. However, agrobiodiversity, which is the national economic and social capital of local communities and the nation, is facing new challenges from the globalization, economic liberalization and changing climatic conditions. An important concern is that a handful of modern crop varieties and breeds are replacing the numerous native varieties and traditional breeds at a fast rate. Agrobiodiversity of one time period can be conserved in ex situ in gene banks and botanical gardens, if they are in threat but loss of knowledge and evolutionary process of gene pools are difficult to conserve unless we provide enabling policy environments and incentives to farmers and the local communities for insitu conservation.

\section{Rationale for farmers' rights}

Farmers rights is considered one of the best options to provide incentives to farmers to conserve agrobiodiversity as farmers are the key actors in the conservation and creation of variability for future innovation in agriculture (Brush, 1992; Swaminathan, 2002; FAO, 2002; Anderson and Winge. 2009). Farmers' rights are important for farmers in Nepal as two-thirds of the populations depend on farming -mainly rural and traditional biodiversity based. Farmers are not only cultivators of agricultural crops but also conservators, creators, users and breeders of genetic resources. Current availability of diversity and technological innovations in agriculture is the product of farmers' unique, evolutionary and historical contributions on genetic resources over millennia (FAO, 2002; Gauchan, 2007). Protecting the rights of the farmers is linked to the issue of ethics, social justice, environmental protection and survival of human race (Swaminathan, 2002). The vital roles that farmers and their varieties play in the livelihood needs of the population and agricultural development of the agro-based countries make promotion of farmers' rights very essential for the agrobiodiversity conservation (FAO, 2002; Srinivasan, 2003; Anderson, 2007). But in context of Nepal's entry into World Trade Organization (WTO) and with the development and promotion of intellectual property rights (IPR) systems and free trade worldwide, farmers lack control, ownership and access of their own genetic resources developed over millennia. Restricting the age-old traditional right of the farmers to control, own and access their own seed varieties jeopardize the possibility of continuously improving and conserving them and reducing the options for future food security of the country.

Despite the completion of six years after the accession to WTO in April 2004, Nepal has not yet made adequate preparation to develop appropriate policies, institutional frameworks and legislation to provide mechanisms for adequate protection of Nepal's rich agricultural 
biodiversity and ensure inalienable rights of farmers and local communities. As a least developed country, Nepal is free to define farmers' rights according to its needs and priorities and develop legislation to protect the rights of farming communities. One of the most popularly discussed measures to promote farmers rights is the creation of legal means for farmers to control others' use of the materials that they have developed and conserved over generation (Halewood et al. 2006). However, there is still lack of well clarity regarding the legal definition of farmers' rights both at the national and international levels (Bhandari, 2004; Anderson, 2005; 2007; GRPI, 2008). Furthermore, the current bill on Plant Variety Protection (2005) of Nepal drafted to meet the requirements of the Trade Related Intellectual Property Rights (TRIPS) of the WTO needs further revisions based on the feed backs and wide consultation from the key stakeholders. In fact, this draft law needs to make clear about its institutional framework and linkages with the broader biodiversity policies and legislation such as Access to Genetic Resources and Benefit Sharing draft Bill (2002). Inspite of the recent awareness and sensitivity about farmers' rights in the intellectual circle, there are no empirical studies eliciting perceptions of different stakeholders on the needs, concepts and components of farmers' rights and institutional mechanisms for ensuring farmers' rights. In this context, a study on stakeholders' perceptions on the provisions and the need of protection of farmers' rights in agrobiodiversity conservation and use was considered very essential in the country. This study, therefore aims to explore contents and provisions of farmers' rights as perceived by the different stakeholders in order to generate information and inputs for development of farmers' rights policies and conservation of agrobiodiversity in Nepal.

This paper is organized as follows. First, following the context and rationale of farmers' rights, it outlines research methods employed for the stakeholder survey. Then, it presents findings of the survey on awareness, content and specific provisions of farmers' rights. This is followed by the description of institutional mechanisms of ensuring farmers' rights based on the combinations of survey findings, literature review and experiences of past work on in situ agrobiodiversity conservation and Genetic Resource Policy Initiative (GRPI) projects in Nepal. Finally conclusions are presented with the suggestions for ensuring and protecting farmers' rights and conservation of agrobiodiversity in Nepal.

\section{Research methods}

The case study on farmers' rights was conducted in the year 2006-07 to document stakeholders' perceptions on the contents, concepts and specific provisions of farmers' rights on genetic resources. First of all, the concepts, contents and specific provisions of farmers' rights were reviewed from various international and national literatures and policy conventions to conceptualize farmers' rights. Then expert consultation meeting was held in Kathmandu for gaining insights and understanding of farmers rights. Based on the literature review, expert interactions and consultation with stakeholders, we found that the concepts of farmers' rights as stated by the International Treaty on Plant Genetic Resources for Food 
and Agriculture (ITPGRFA) were found most relevant in Nepalese context. Accordingly, this study used this framework of farmers' rights for designing the specific survey instruments. The study then, employed sample survey of diverse stakeholders employing 3M (multidisciplinary, multistakeholder, multi-sectoral) approach under global component of Nepal's Genetic Resource Policy Initiative (GRPI) Project. Field survey elicited the perception of different stakeholders on farmers' rights through individual interviews, consultation meetings and focus group discussion. The focus of the study was on participatory action research which involved not only the field survey of stakeholders but also simultaneously creating awareness and capacity building of these key stakeholders. We accomplished individual survey of 124 diverse stakeholders from four development regions across the country representing farmers and representatives of community based organizations (CBOs), I/NGOs, private sectors, and government planners (policy makers) including representatives of public sector $\mathrm{R} \& \mathrm{D}$ organizations. The information was supplemented and validated through the feed backs and consensus building from stakeholder consultation meeting conducted in four developmental regions (eastern, central, western, and mid-western) in Nepal. The survey instruments (both focus group discussion and individual interviews) covered information related to level of awareness of stakeholders on farmers' rights, agrobiodiversity conservation and perception of stakeholders on content and specific provisions of farmers' rights. In addition, stakeholders were also consulted on the mechanisms for implementing and ensuring farmers' rights. Data and information collected from the survey were compiled, analysed and synthesized using tables, charts and flow diagrams.

\section{Findings}

This section provides the findings of interview of various stakeholders on the concepts, and specific provisions of farmers' rights based on the perceptions of different stakeholders. The representatives of various stakeholders that involve farmers, $\mathrm{CBOs}$, private and public sectors and I/NGOs provided their critical viewpoints, suggestions and information during the survey process which are synthesized and described below.

\section{Proportion of different type of stakeholders}

A large number of stakeholders representing farming communities, NGOs, private sectors (agro entrepreneurs), and government R \& D and policy making institutions have interest and influence on farmers rights, food security and agro-biodiversity conservation in Nepal. The proportion of different type of stakeholders surveyed for the study is presented in Fig 1. The data show that about half of the stakeholders $(51 \% n=63)$ surveyed were farmers and their representatives from local community based organization (CBOs), which are represented by farmers' groups, cooperatives and farmers' professional associations. Onefourth of the surveyed stakeholders $(25 \%)$ were from public $\mathrm{R} \& \mathrm{D}$ organizations particularly research scientists from Nepal Agricultural Research Council (NARC central 
divisions and regional stations), Nepal Academy of Science and Technology (NAST), Universities (IAAS, HICAST) and district extension officers from Department of Agriculture and Department of Livestock Services. Both international and local nongovernmental organizations (I/NGOs) represent $10 \%$ of the respondents. The private sector represented by agro entrepreneurs (seed traders and agro industries) constitute $8 \%$ of the stakeholders. Policy makers / planners, particularly senior officials of the Ministry of Agriculture and Cooperatives (MoAC), Forest and Soil Conservation, Ministry of Industries, Commerce and Supplies and National Planning Commission (NPC) represented about $6 \%$ of the respondents.

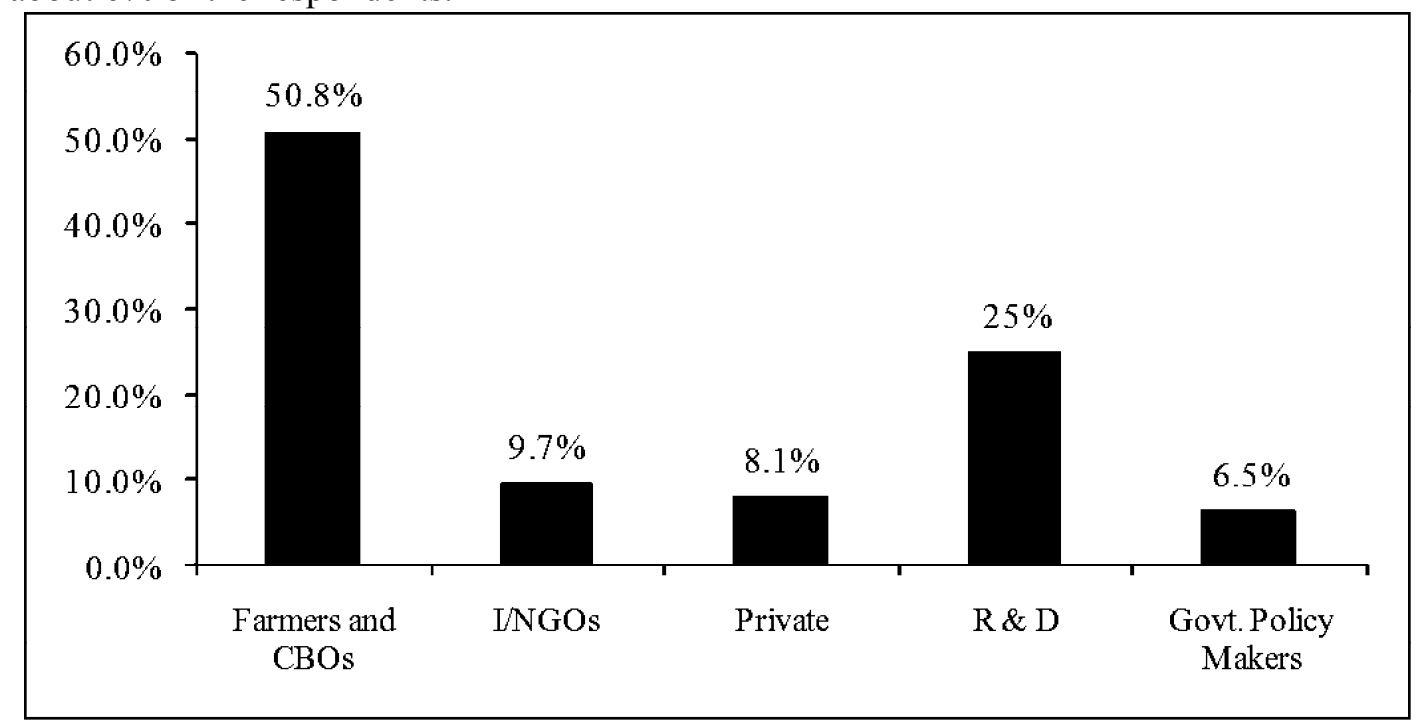

Figure 1. Proportion of different stakeholders surveyed in agro-biodiversity conservation

\section{Awareness of stakeholders on farmers' rights}

Farmers and other stakeholders perceive that genetic erosion and bio-piracy is wide spread across locations in different crops and livestock breeds. Therefore, they have a high priority to protect the rights of farmers and local communities to conserve rich biodiversity of agriculture. About $95 \%$ of the sample stakeholders were aware of importance of conservation of agro biodiversity and need to protect farmers' rights. Among them, majority were against free exchange and free transfer of genetic resources from owners (farmers) to seed companies and other concerned parties. The stakeholders are more concerned with requirement of prior informed consent (PIC) and restricted exchange of genetic resources even between farmers and public research and development organizations. Issues of the farmers' rights and protection of genetic resources were considered more important among professionals working in non-governmental organizations, public agricultural development institutions and representatives of CBOs. Many stakeholders (42\%) also perceived that plant breeders' rights is important for providing incentives to plant breeders for developing new 
varieties. This was more emphasized by the research professionals (plant breeders) and representative of private seed companies.

\section{Concept and component of farmers' rights}

The response to the survey was extremely positive indicating a need of provision of farmers' rights in the country's policy and laws. About $71 \%$ of the surveyed stakeholders perceived that farmers' right is an important right to be provided to the farming community in the country. Different stakeholders have perceived differently on the content, definition and provisions of farmers' rights as there are no well accepted official definition of farmers' rights to date. However, most of the stakeholders considered farmers rights in terms of ownership rights to seeds, traditional knowledge, rights to participate in benefit sharing and participation in policy decision making. Some of them also considered farmers' rights mean compensation rights to farmers during the crop failure. Few of the stakeholders also perceived the other rights of farmers, which refers to rights of farmers to get fair price from selling of their seeds. The findings of the survey on the provisions of farmers' rights were mostly in line with the provision of ITPGRFA and similar to the provisions specified in proposed draft Nepalese Plant Variety Protection (PVP) and Farmers' Rights bill (2005), though some stakeholders had different views. The key components of farmers' rights as synthesized from survey are outlined here. These include (i) rights to seeds (right to save, exchange and sell own farm produced seed) (ii) rights to traditional knowledge on their genetic resources (iii) rights to participate in equitable share of benefits (iv) rights to participate in policy decision making and (v) rights to claim compensation for losses due to bad quality seeds or wrong information. Each of these are briefly discussed below:

\section{Right to seed}

Right to seed is a fundamental right of the farmers as perceived by all the stakeholders. It includes the rights of farmers' over their traditional practice of saving; using, exchanging, and selling farm saved seeds/propagating materials (FAO, 2002; FAO, 2009). Survey findings showed that about $70 \%$ of the stakeholders responded that farmers' should exercise their traditional right on seed enjoyed by them over generation. Only $4 \%$ of the respondent perceived that the rights on seed should also exist on government agencies. Similarly $19 \%$ of the stakeholders are in view that the rights on seed be exercised jointly by farmers and the nation state.

\section{Rights to traditional knowledge}

Small farmers in traditional farming systems not only conserve seeds of diverse traditional varieties but also inherit and hold rich traditional knowledge about their cultivation practices, food culture and medicinal use. Traditional knowledge (TK) is knowledge generated by the local communities over generation through their continuous process of seed selection, adaptation and crop improvement. Therefore, they should get rights to 
traditional knowledge on agricultural genetic resources. Traditional knowledge held by local communities is related to implementation of the Convention on Biological Diversity (Article $8(\mathrm{j})$ of the CBD) and also one of the components of farmers' rights as recognised by ITPGRFA in Article 9.2(a). According to the survey, 70\% of the stakeholders perceived that farmers should have rights over traditional knowledge, whilst $23 \%$ reported that these rights should jointly vest with government and farmers. However, only $7 \%$ of the stakeholders were in view that rights to traditional knowledge should exist with policy makers, agricultural professionals and seed companies.

\section{Rights to participate in equitable sharing of benefits}

The Farmers' Rights concept also calls for the full participation of farmers in the results of the benefits resulting from the use of agrobiodiversity related knowledge. It is an important element in the FAO International Treaty of PGRFA (2001) which recognizes "benefitsharing" as one of the components of Farmers' Rights. This is also a major goal of the CBD (1992), which emphasizes the fair and equitable sharing of benefits derived from the commercial use of genetic resources. The survey findings indicated that about $90 \%$ of the stakeholders have the opinion that there is a need of benefit sharing mechanisms with farmers and farming communities from the commercialization of genetic resources. The mechanisms of benefit sharing should include both financial and non-financial means as indicated by $98 \%$ of these stakeholders.

\section{Rights to participate in policy decision making}

Farmers' participation in policy decision making is very essential in sustainable conservation and use of genetic resources. This is one of the four components of farmers' rights as recognized by ITPGRFA in Article 9.2(c) "the right to participate in making decisions" at the national level "on matters related to the conservation and sustainable use" of PGRFA. There are various ways and mechanisms through which farmers' participation in policy making is assured. These include participation in seminar/workshop for information sharing, participation in consultation meeting for specific policy feedbacks and participation in policy decisions. The survey findings indicated that at present seminar/workshop is a chief means of farmers' participation in policy decisions as indicated by $42 \%$ of the sample stakeholders. Most of the cases (52\%) farmers' are not usually consulted for participation in policy making.

\section{Rights to claim compensation for losses due to use of new protected varieties}

Farmers should also get rights to claim compensation for losses incurred due to use of new breeder protected varieties depending on the contexts and situations. In some cases, situation may arise when farmers use new protected varieties (with breeders rights or patent rights), the crop may fail and farmers may incur losses due to bad quality of the seeds or wrong information supplied about the new varieties. In addition, there may be cases where breeders 
may develop new variety from the use of farmers' varieties without prior consent of the farmers. In such cases also, farmers should get claim of ownership rights and get equitable share of benefits derived from the commercialization of such new varieties. The survey findings showed that $65 \%$ of the stakeholders (farmers and others) strongly perceived to have compensation rights for farmers, when there is a violation of rights by breeders of new varieties.

\section{Institutional mechanisms for ensuring farmers rights}

Farmers' right to genetic resources is one of the fundamental rights to recognize the individual and collective contribution of farming people as well as to provide incentives to them for their efforts in conservation and sustainable development of agriculture. Nepal has initiated drafting of "Plant Variety Protection and Farmers' Rights Act" (2005), to protect plant varieties, provide incentives to plant breeders and protect the rights of the farmers. While the policy and legal frameworks are essential at the national level to recognize, protect and implement the rights of farmers and communities, its practical implementation remains biggest challenge in a least developed agro-based country like Nepal. Hence, there is a need of appropriate local level institutional mechanisms and efforts for effective implementation and enforcement of farmers' rights (Gauchan, 2005; GRPI, 2008). Accordingly, this study has identified options for the institutional mechanisms to ensuring farmers' rights and conservation of agrobiodiversity both at the local and national level which are outlined below:

\section{Local level institutional mechanisms}

The important local level institutional mechanisms suggested here for ensuring farmers' rights and conservation of agrobiodiversity are presented in Fig 2, which include (i) local biodiversity management committee to coordinate, manage and use of local genetic resources and provide a mechanisms for prior informed consent (PIC) and equitable sharing of benefits at the local level (ii) community biodiversity register (CBR) to document community genetic resources and knowledge and check biopiracy (iii) participatory plant breeding (PPB) groups for ensuring farmers' access to diverse genetic resources and enhancing their knowledge, skills and rights on the genetic resources and traditional knowledge (iv) community biodiversity fairs to create sense of awareness and recognition of local genetic resources among local communities (v) community seed bank to conserve, exchange, manage and enhance access and ownership of diverse genetic resources and knowledge in the community (vi) local community trust fund for collecting funds arising out from various sources including local benefits sharing mechanism with third parties. Among various above mentioned options, registration of agrobiodiversity at the community level through community biodiversity register (CBR) is one of the important mechanisms for supporting claims of local varieties and knowledge as an evidence of farmers' rights and prevents unjust appropriation and use of local genes by outsiders. 


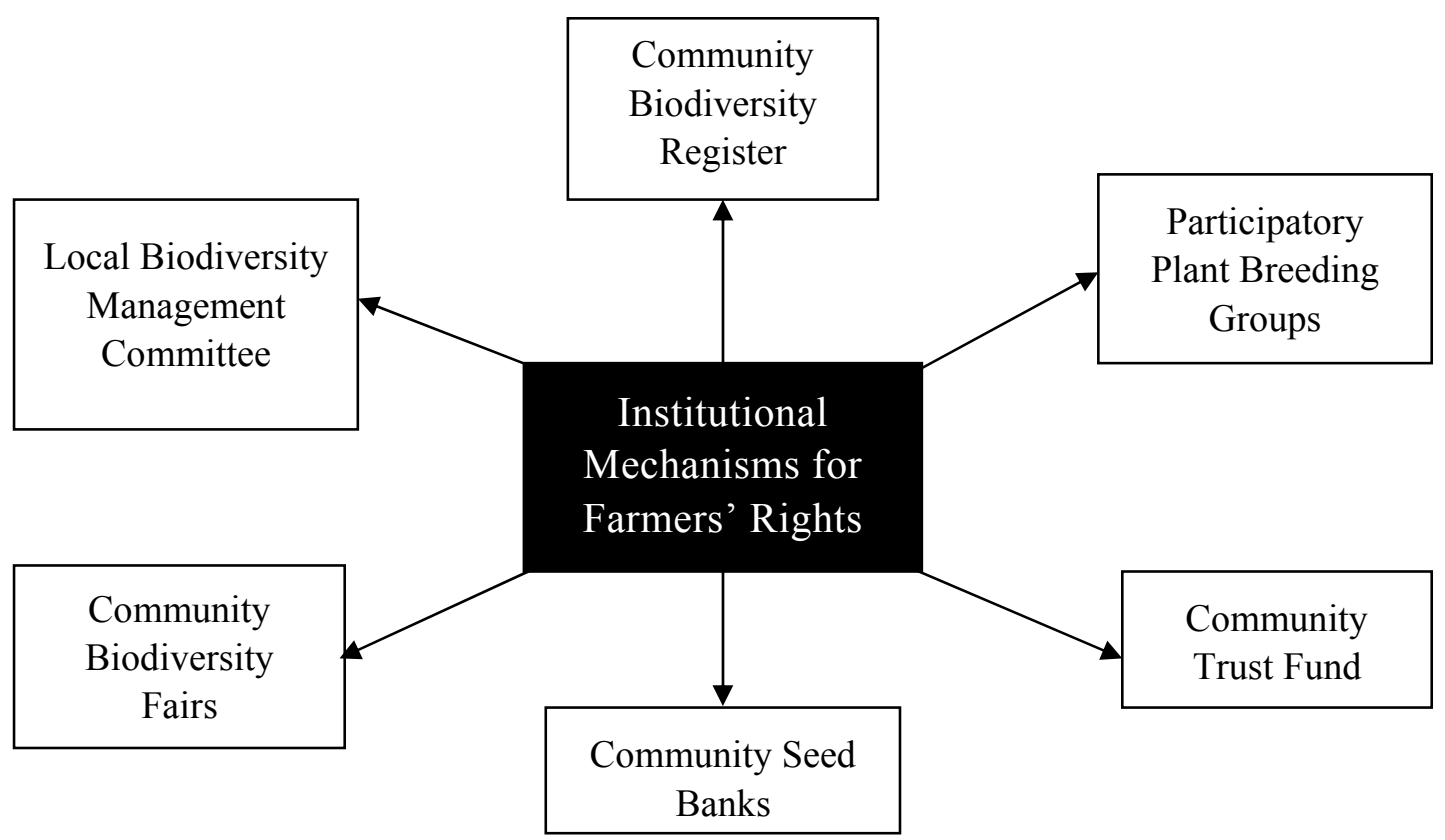

Figure 2. Suggested institutional mechanisms for ensuring farmers rights in Nepal

\section{National level institutional mechanisms}

Institutional mechanisms for implementing and realizing farmers' rights are also needed at the national level through appropriate linkages and coordination with the relevant international and local level organizations. This linkage should be relevant to protection of farmers' rights and agrobiodiversity conservation. This may include establishment of National Biodiversity Council at the centre as suggested by the proposed Access and Benefit Sharing Draft Bills (2002) of Ministry of Forest and Soil Conservation, Nepal. Moreover, it may be more appropriate to strengthen National Agrobiodiversity Conservation Committee (NABC) at the Ministry of Agriculture and Cooperatives for the implementation of institutional provisions and programmes for agrobiodiversity conservation and farmers rights. Establishment of a "National Biodiversity and Gene Fund" may also be an option to implement the provisions of benefit sharing arrangement and realization of farmers' rights at the national level drawing the funds from both national and international sources.

\section{Conclusion}

Farmers' right is the basic right of farmers, which is considered important to farmers for the conservation of agro biodiversity, checking biopiracy and fostering innovations in agriculture. The components of farmers' rights as perceived by the stakeholders include rights to seeds, traditional knowledge, and benefit sharing and farmers' participating in decision making. The concepts of farmers' rights identified from this study were similar to 
the farmers' rights concept as stated in Article 9 of International Treaty on Plant Genetic Resources for Food and Agriculture (ITPGRFA) and Indian Plant Variety Protection and Farmers' Rights Act (2002).The currently proposed "Plant Variety Protection' and Farmers' Rights Bill" (2005) of Nepal also uses similar concepts.

All of the surveyed stakeholders feel that farmers are the owners of the genetic resources and they should have rights to save, use and sell. They should be consulted for the access of the genetic resources and benefit sharing with them. Without their prior informed consent (PIC), the genetic resources should not be given permission to the third parties for their use. Governments and farmers both are the important stakeholders for access and benefit sharing management at the national and local level respectively. Because of an agro based economy with a subsistence farming systems, Nepal agreed to have a suigeneris plant variety protection (PVP) law with balancing rights of farmers and plant breeders to meet WTO/TRIPS requirement (SWATEE, 2006; FAO, 2008; Shrestha et al., 2009). Inclusion of farmers' rights in the proposed suigeneris PVP legislation is essential not only to protect the rights of farming communities but also to conserve agro-biodiversity and provide incentives to farmers for future innovation in agriculture. However, the major obstacles for ensuring and strengthening farmers' rights in the proposed draft PVP legislation is to develop policy, institutional and practical mechanisms to balance rights of breeders with that of farmers (GRPI, 2008). Therefore, as suggested above, the country needs to employ and promote institutional mechanisms for ensuring farmers' rights and conservation of agrobiodiversity both at the local and national levels. Establishment of different institutional groups and mechanisms such as community biodiversity management committee, local trust fund, community biodiversity registrations, biodiversity fairs, community seed banks and participatory plant breeding groups are essential to ensuring and strengthening farmers' rights and promoting in situ conservation of agrobiodiversity.

In addition, establishment of a suitable institutional mechanism and structure at the national level is needed for protecting farmers' rights and facilitating access and benefit sharing mechanisms. This may include establishment of national biodiversity council at the centre as suggested by the proposed Access and Benefit Sharing Draft Bills (2002) of Nepal. Furthermore, specific policies and action plans are needed to enhance the capacity of farmers, local communities and national policy makers in implementing the institutional mechanisms, formulating suitable farmer-focus policies and legislations. Similarly, an action research programme is further required to elaborate the definition and contents of farmers' rights and develop appropriate applicable framework and formula for access and equitable sharing of benefits with the farming communities. This will help to establish a scientific basis for farmers' rights and benefit sharing mechanisms drawing on social, economic and biological sciences. Such scientific studies will also be helpful to design governance of agrobiodiversity and benefit sharing in the changed context of state restructuring and federal system of the country. 


\section{Acknowledgement}

This paper is the output of Genetic Resource Policy Initiative Project (GRPI) project (20032007), Nepal funded through Bioversity International, Rome. I am very much thankful to Dr. MP Upadhyay, former national project coordinator GRPI, Nepal for the input in the design of the survey and the members of the GRPI team for their insights in the research process. Special thanks go to respondent stakeholders for giving their valuable time and interest in the interviews, consultation meetings and group discussions.

\section{References}

ADB/MoF (Asian Development Bank / Ministry of Finance). 2010. Improving Seed Security through the Expansion of Seed Multiplication Farms in the Public, Private and Cooperative Sectors in Nepal. Economic Policy Network II (ADB TA 7042-NEP), Thematic Area Agriculture and Rural Development. Draft Final Report. Asian Development Bank (ADB) and Ministry of Finance (MoF), Kathmandu, Nepal.

Anderson, R. 2005.The History of Farmers' Rights. A Guide to Central Documents and Literature. Background study 1.The Farmers Right Project. FNI Report 8/2005, Norway.

Anderson R. 2007. Protecting Farmers' Rights in the Global IPR Regime. Challenges and Options. Trade Insights and Development Concern in South Asia. A dialogue on Trade and Development in South Asia. Vol 3. No. 2. 2007

Andersen, R and T Winge. 2009. The Plant Treaty and Farmers' Rights: Implementation Issues for South Asia. VI+48.Kathmandu: South Asia Watch on Trade, Economics \& Environment (SAWTEE).

Baniya, B, A Subedi, R Rana, R Tiwari, P Chaudhary, S Shrestha, P Tiwari, R Yadav, D Gauchan, B Sthapit. 2003. What are the processes used to maintain the genetic diversity on-farm ? In: Gauchan D, B Sthapit, DI Jarvis (eds.). Agrobiodiversity conservation on-farm: Nepal's contribution to a scientific basis for national policy recommendations. IPGRI, Rome.

Bhandari, S. 2004. Farmers' Rights (in relation to plant genetic resources). Action Aid Nepal.

Brush, SB. 1992. Farmers' rights and genetic conservation in traditional farming Systems, World Development. 20:1617-1630

CBD (Convention on biological diversity). 2001. Hand book of the Convention on Biological Diversity (CBD). Secretariat of the Convention on Biological Diversity (CBD). United Nation Environmental Program (UNEP). Earthscan Publication, London.

FAO (Food and Agriculture Organization). 2002. International Treaty on Plant Genetic Resources for Food and Agriculture. Food and Agriculture Organization (FAO), Rome

Gauchan D, BR Sthapit, DI Jarvis. 2003. Agrobiodiversity Conservation On-farm: Nepal's Contribution to a Scientific basis for National Policy Recommendations. IPGRI, Rome, Italy 
Gauchan, D. 2005. Strategies for establishing farmers' rights at the grassroots level. Briefing Paper (Nepali Version). Vol 2, Ashad (June-July), 2005. Pro-Public, Kathmandu, Nepal

Gauchan, D. 2008. Farmers' Rights in Nepal: Context, Concepts and Perceptions. Agriculture Development Journal, Vol.4 (4) 1-14: Directorate of Agriculture Training, Department of Agriculture, Pulchcowk, Lalitpur, Nepal.

GRPI (Genetic resources policy initiative). 2008. Genetic Resources Policy Initiative : strengthening capacity to analyze national options-Nepal component. Annual technical report to IDRC 2007. Bioversity International, Rome, Italy.

Halewood M, JJ Cherfas, JM, Engels, TH Hazekamp, T Hodgkin, J.Robinson. 2006. Farmers, landraces, and property rights: challenges to allocating sui generis intellectual property rights to communities over their varieties. In: Biber-Klemm S, T Cottier (eds). Rights to plant genetic resources and traditional knowledge: Basic issues and perspectives. CABI Wallingford, UK.pp. 173-202.

SAWTEE (Asouth Asia watch on trade, economics and environment). 2006. Access, Benefit Sharing and Prior Informed Consent under CBD, ITPGRFA and TRIPS. Legal mechanism in South Asia. Research Report viii+50, South Asia Watch on Trade, Economics \& Environment (SAWTEE), Kathmandu.

Shrestha, PK, K Adhikari and MN Shrestha. 2009. Implications of Plant Variety Protection and Farmers' Rights Bill on Seed Production and Marketing in Nepal. Proceedings of the Fourth National Seed Seminar, 19-20 June, 2008. National Seed Board, Ministry of Agriculture and Cooperatives, Kathmandu, Nepal.

Srinivasan, C. 2003. Exploring the feasibility of Farmers' Rights. Development Policy Review, 2003, $21(4): 419-447$.

Swaminathan, MS. 2002. The past, present and future contribution of farmers to the conservation and development of genetic diversity. In: Engels, JMM, VR, Rao, AHD Brown and MT Jackson (eds.). Managing Plant Genetic Diversity. IPGRI, Rome. 